\title{
Randomized trial of the anti-FGF23 antibody KRN23 in X-linked hypophosphatemia
}

\author{
Thomas O. Carpenter, ${ }^{1}$ Erik A. Imel, ${ }^{2}$ Mary D. Ruppe, ${ }^{3}$ Thomas J. Weber, ${ }^{4}$ Mark A. Klausner, ${ }^{5}$ \\ Margaret M. Wooddell, ${ }^{5}$ Tetsuyoshi Kawakami, ${ }^{5}$ Takahiro Ito, ${ }^{5}$ Xiaoping Zhang, ${ }^{5}$ \\ Jeffrey Humphrey, ${ }^{5}$ Karl L. Insogna, ${ }^{1}$ and Munro Peacock ${ }^{2}$
}

${ }^{1}$ Yale Center for X-Linked Hypophosphatemia, Yale University School of Medicine, New Haven, Connecticut, USA. 2Indiana University School of Medicine, Indianapolis, Indiana, USA. ${ }^{3}$ The Methodist Hospital, Houston, Texas, USA. ${ }^{4}$ Duke Clinical Bone Laboratories, Duke University Medical Center, Durham, North Carolina, USA. ${ }^{5}$ Kyowa Hakko Kirin Pharma Inc., Princeton, New Jersey, USA.

\begin{abstract}
Background. X-linked hypophosphatemia (XLH) is the most common heritable form of rickets and osteomalacia. XLH-associated mutations in phosphate-regulating endopeptidase (PHEX) result in elevated serum FGF23, decreased renal phosphate reabsorption, and low serum concentrations of phosphate (inorganic phosphorus, $\mathrm{Pi}$ ) and 1,25-dihydroxyvitamin $\mathrm{D}\left[1,25(\mathrm{OH})_{2} \mathrm{D}\right]$. KRN23 is a human anti-FGF23 antibody developed as a potential treatment for XLH. Here, we have assessed the safety, tolerability, pharmacokinetics (PK), pharmacodynamics (PD), and immunogenicity of KRN23 following a single i.v. or s.c. dose of KRN23 in adults with XLH.
\end{abstract}

Methods. Thirty-eight XLH patients were randomized to receive a single dose of KRN23 $(0.003-0.3 \mathrm{mg} / \mathrm{kg}$ i.v. or 0.1-1 mg/kg s.c.) or placebo. PK, PD, immunogenicity, safety, and tolerability were assessed for up to 50 days.

Results. KRN23 significantly increased the maximum renal tubular threshold for phosphate reabsorption (TmP/GFR), serum $P i$, and $1,25(\mathrm{OH})_{2} \mathrm{D}$ compared with that of placebo $(P<0.01)$. The maximum serum $P i$ concentration occurred later following s.c. dosing (8-15 days) compared with that seen with i.v. dosing (0.5-4 days). The effect duration was dose related and persisted longer in patients who received s.c. administration. Changes from baseline in $T m P / G F R$, serum $P i$, and serum $1,25(\mathrm{OH})_{2} D$ correlated with serum $K R N 23$ concentrations. The mean $\mathrm{t}_{1 / 2}$ of KRN23 was 8-12 days after i.v. administration and 13-19 days after s.c. administration. Patients did not exhibit increased nephrocalcinosis or develop hypercalciuria, hypercalcemia, anti-KRN23 antibodies, or elevated serum parathyroid hormone (PTH) or creatinine.

Conclusion. KRN23 increased TmP/GFR, serum Pi, and serum 1,25(OH $)_{2} \mathrm{D}$. The positive effect of KR23 on serum $P i$ and its favorable safety profile suggest utility for KRN23 in XLH patients.

Trial registration. Clinicaltrials.gov NCT00830674.

Funding. Kyowa Hakko Kirin Pharma, Inc.

\section{Introduction}

X-linked hypophosphatemia (XLH), the most common heritable form of rickets or osteomalacia, occurs due to loss-of-function mutations in PHEX, which result in elevated blood levels of fibroblast growth factor 23 (FGF23) (1, 2). FGF23 decreases renal tubular reabsorption of phosphate by reducing the abundance and possibly the activity of sodium-phosphate cotransporters on the apical membrane of proximal tubular epithelium, thereby reducing serum phosphate (measured as inorganic phosphorus, Pi) concentrations (3-5). Elevated FGF23 also decreases renal 1 - $\alpha$-hydroxylase activity, leading to low or inappropriately normal blood levels of 1,25-dihydroxyvitamin D $\left[1,25(\mathrm{OH})_{2} \mathrm{D}\right](1,2)$.

Note regarding evaluation of this manuscript: Manuscripts authored by scientists associated with Duke University, The University of North Carolina at Chapel Hill, Duke-NUS, and the Sanford-Burnham Medical Research Institute are handled not by members of the editorial board but rather by the science editors, who consult with selected external editors and reviewers.

Conflict of interest: Thomas O. Carpenter and Mary D. Ruppe have received consulting fees from Kyowa Hakko Kirin Pharma Inc. Mark A. Klausner, Tetsuyoshi Kawaka$\mathrm{mi}$, Takahiro Ito, Xiaoping Zhang, and Jeffrey Humphrey are currently employed, and Margaret M. Wooddell was previously employed, by Kyowa Hakko Kirin Pharma Inc. Citation for this article: J Clin Invest. 2014;124(4):1587-1597. doi:10.1172/JCI72829.
Due, at least in part, to chronic hypophosphatemia, skeletal mineralization is compromised, causing lower-extremity bowing and other rachitic skeletal abnormalities. The mineralization defect persists in adulthood with continuing osteomalacia that leads to long-term complications including pseudofractures in many patients. Dental abscesses can occur beginning in childhood, and enthesopathy, osteophytes, and osteoarthritis may occur as later complications of the disease $(6,7)$. Currently available therapy (typically oral calcitriol and phosphate) aids mineralization by increasing net phosphate intake and intestinal absorption and transiently increases serum Pi concentration. However, complications of treatment including hypercalciuria, nephrocalcinosis, and hyperparathyroidism may occur, and the underlying renal tubular defect in phosphate reabsorption is not corrected by this therapy $(8,9)$. Safer and more efficacious therapies are needed $(9)$.

KRN23 is a recombinant human $\mathrm{IgG}_{1}$ monoclonal antibody that binds to FGF23, blocking its biologic activity. Both intact and fragmented FGF23 polypeptides are immunoprecipitated with KRN23 (10). In a Phex-deficient hypophosphatemic mouse model, a single injection of anti-murine FGF23 antibody corrected the hypophosphatemia and increased serum $1,25(\mathrm{OH})_{2} \mathrm{D}$ (11). These effects were accompanied by increased expression of 


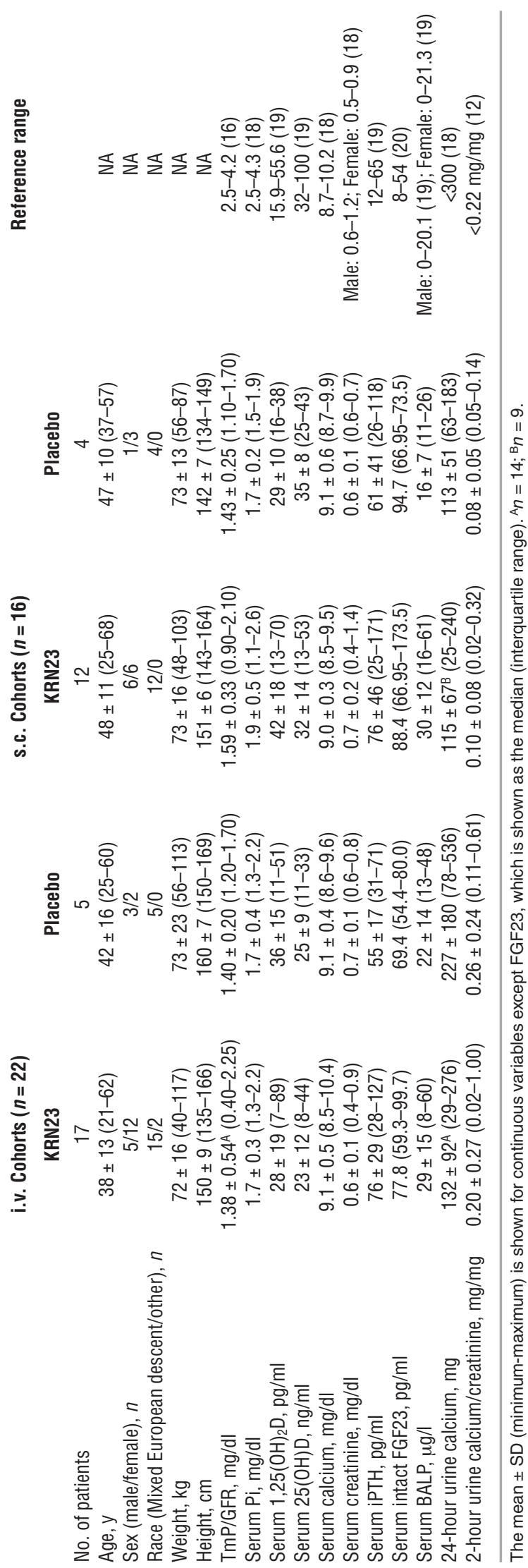

type IIa sodium-phosphate cotransporters and 1- $\alpha$-hydroxylase and decreased expression of 24-hydroxylase in the kidney (11). Repeated injections ameliorated rickets as assessed by the correction of growth impairment, defective mineralization, and abnormal cartilage development. These results in mice not only indicate that increased FGF23 underlies hypophosphatemic rickets in Phex-deficient Hyp mice, but suggest the potential utility of FGF23 antibodies to treat XLH.

To assess the capacity of KRN23 to correct renal phosphate reabsorption and to increase serum $\mathrm{Pi}$ and $1,25(\mathrm{OH})_{2} \mathrm{D}$ levels in humans, we performed this phase 1 , double-blind, randomized, placebo-controlled, single-dose study of KRN23 in adults with XLH. The trial design was chosen to minimize variability of the evaluation and to provide an unbiased evaluation of the treatment by avoiding the confounding effects of other factors.

The primary objective of this study was to assess the safety and tolerability of single i.v. or s.c. doses of KRN23. Secondary objectives included assessments of the effects on serum and urine mineral biochemistry and of the pharmacokinetics (PK), pharmacodynamics (PD), and immunogenicity of KRN23.

\section{Results}

Patient characteristics. The clinical characteristics of the patients enrolled in this study are listed in Table 1, and the CONSORT diagram for this trial is depicted in Figure 1. For the total of 38 patients, 22 participated in the i.v. group (17 KRN23, 5 placebo) and 16 in the s.c. group (12 KRN23, 4 placebo). Baseline age, weight, sex, and height were comparable among the groups. Prior to the study, 25 of the 38 patients were taking either phosphate preparations (2 patients), vitamin D preparations (6 patients), or both (17 patients). Prior to dosing, the mean serum Pi concentrations and the ratio of renal tubular maximum for phosphate reabsorption to glomerular filtration rate ( $\mathrm{TmP} / \mathrm{GFR})$ were comparable among the groups and were lower than the normal reference ranges. Baseline values for serum calcium, creatinine, $1,25(\mathrm{OH})_{2} \mathrm{D}$, 25-hydroxyvitamin D [25(OH)D], 24-hour urine calcium excretion, and the 2 -hour urine calcium/creatinine ratio were in the ranges typical of those observed in adults with XLH and did not differ among the treatment groups. Twenty-four hour urine calcium excretion exceeded $400 \mathrm{mg}$ in only one placebo patient $(536 \mathrm{mg})$. As expected in patients with XLH, the baseline mean values for intact parathyroid hormone (iPTH) and bone alkaline phosphatase (BALP) were near or above the upper limit of the normal ranges in all four treatment groups. Serum Pi showed no correlation with serum FGF23 at baseline $(r=-0.03)$.

TmP/GFR. For patients in the i.v. group treated with KRN23, the maximum mean TmP/GFR occurred between days 2 and 4 (Figure 2A), and significant increases as compared with placebo were evident in the three higher-dose groups $(0.03,0.1$, and 0.3 $\mathrm{mg} / \mathrm{kg}, P \leq 0.006$; Table 2). Increases in TmP/GFR persisted for 3 to 4 weeks after dosing for the 0.1 - and $0.3-\mathrm{mg} / \mathrm{kg}$ doses. The AUC to the last measurable time point $\left(\mathrm{AUC}_{\text {last }}\right)$ for the change from baseline in TmP/GFR increased as the i.v. dose increased from 0.03 to $0.3 \mathrm{mg} / \mathrm{kg}$, however, there was no statistically significant dose relationship (Table 3 ).

The maximum mean TmP/GFR was attained at much later time points in the s.c. group (days 4-22) than in the i.v. group (days 2-4) for patients receiving KRN23 (Figure 2, A and B). 


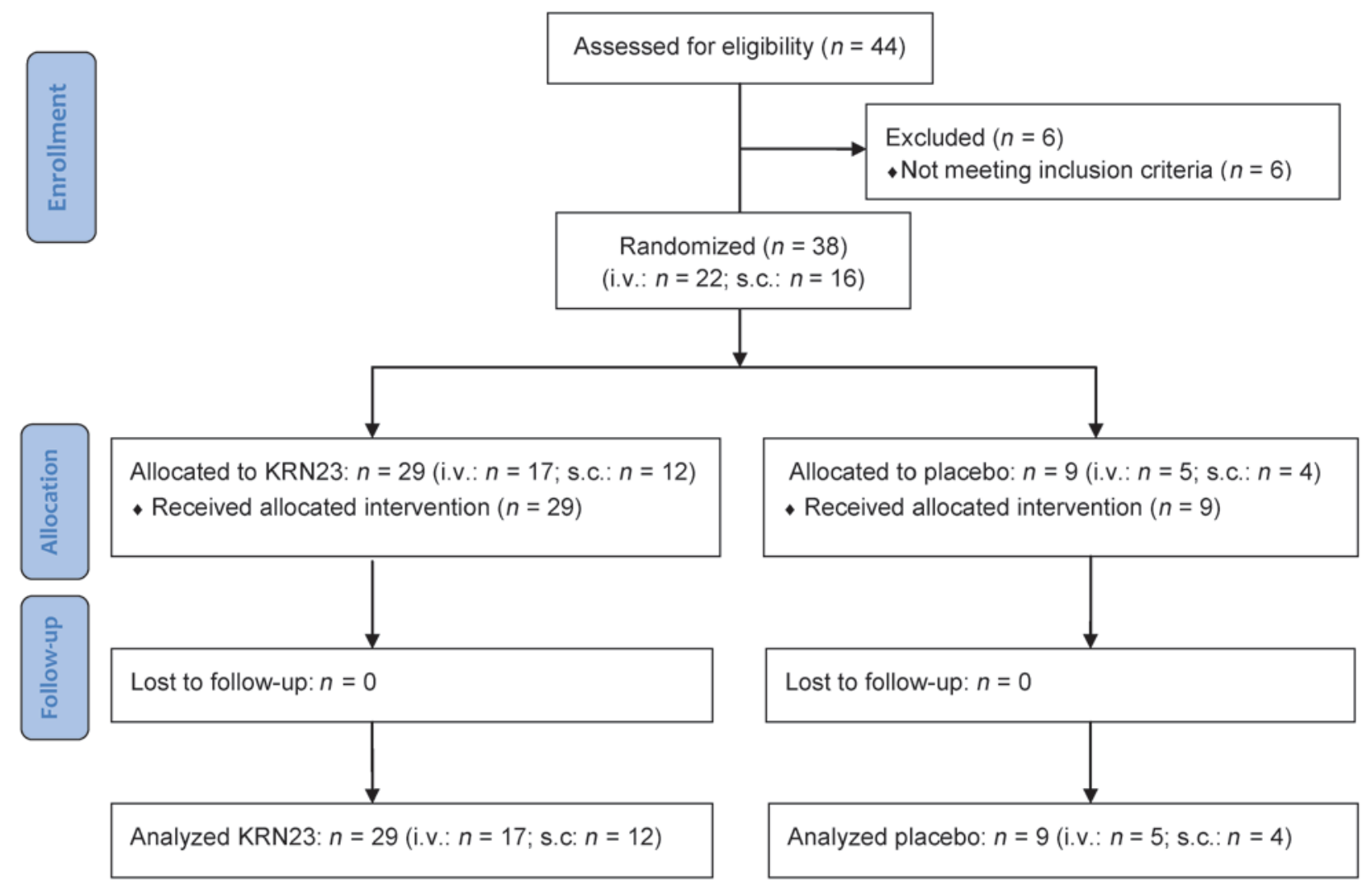

\section{Figure 1}

CONSORT diagram for this phase I randomized clinical trial. Forty-four patients were screened, 38 eligible patients were randomized, and 6 were excluded. All 38 patients received single-dose treatment by i.v $(n=22)$ or s.c. $(n=16)$ administration of either KRN23 $(n=29)$ or KRN23 placebo $(n=9)$. All patients underwent complete follow-up and analysis.

Increases from baseline in TmP/GFR significantly exceeded placebo at all four s.c. dose levels $(0.1,0.3,0.6$, and $1 \mathrm{mg} / \mathrm{kg}, P<0.001$; Table 4), and increases persisted beyond 4 weeks. The $\mathrm{AUC}_{\text {last }}$ for the change in TmP/GFR from baseline increased numerically as the s.c. dose increased from 0.1 to $1 \mathrm{mg} / \mathrm{kg}$, although there was no statistically significant dose relationship (Table 5).

Serum $P i$. In the i.v. group, the maximum mean serum Pi was observed on days 4 and 5 in the 0.3 - and $0.1-\mathrm{mg} / \mathrm{kg}$ dose groups, respectively, and returned toward baseline by day 29 (Figure 2C). The serum Pi never exceeded $4.5 \mathrm{mg} / \mathrm{dl}$ in any patient in the i.v. group. The increase in serum Pi was significant for the 0.1 and $0.3 \mathrm{mg} / \mathrm{kg}$ doses compared with that found in placebo $(P<0.01$; Table 2). The $\mathrm{AUC}_{\text {last }}$ for the change from baseline in serum $\mathrm{Pi}$ increased in a dose-related manner from 0.003 to $0.3 \mathrm{mg} / \mathrm{kg}$ (Table 3).

In the s.c. treatment group (Figure 2D), the maximum mean serum Pi occurred between days 8 and 15 and returned to baseline by day 50 for patients receiving KRN23. The increase in serum Pi was statistically significant compared with placebo within the dose range of 0.3 to $1 \mathrm{mg} / \mathrm{kg}(P<0.001$; Table 4$)$. The highest mean $( \pm \mathrm{SD})$ serum $\mathrm{Pi}$ in the s.c. dose groups was $3.9 \pm$ $1.18 \mathrm{mg} / \mathrm{dl}$ on day $12 \mathrm{in}$ the $0.6-\mathrm{mg} / \mathrm{kg}$ dose group. The serum $\mathrm{Pi}$ in 1 patient receiving $0.6 \mathrm{mg} / \mathrm{kg}$ s.c. exceeded $4.5 \mathrm{mg} / \mathrm{dl}$ at a single time point $(5.2 \mathrm{mg} / \mathrm{dl}$ on day 11$)$; all subsequent values for serum $P i$ for this patient were within the normal range from days 17 through 36 and declined to values similar to those observed at baseline by day 50. The $\mathrm{AUC}_{\text {last }}$ for the change in serum Pi from baseline increased as the dose increased from 0.1 to $1 \mathrm{mg} / \mathrm{kg}$ (Table 5). The $\mathrm{AUC}_{\text {last }}$ for the change in serum Pi from baseline was similar for i.v. and s.c. treatments at the same dose levels $(0.1$ and $0.3 \mathrm{mg} / \mathrm{kg}$ ) (Tables 3 and 5).

Serum $1,25(\mathrm{OH})_{2} D$. After i.v. administration, statistically significant increases in serum $1,25(\mathrm{OH})_{2} \mathrm{D}$ occurred with each dose in the 0.01 - to $0.3-\mathrm{mg} / \mathrm{kg}$ range compared with placebo (Figure $2 \mathrm{E}$, $P \leq 0.05$; Table 2). The maximum mean serum $1,25(\mathrm{OH})_{2} \mathrm{D}$ level occurred between days 1 and 3 (Figure 2E), followed by a rapid decrease within the next few days and near normalization by day 8. The mean $\mathrm{AUC}_{\text {last }}$ for the change in $1,25(\mathrm{OH})_{2} \mathrm{D}$ from baseline increased as the dose increased from 0.003 to $0.3 \mathrm{mg} / \mathrm{kg}$; however, there was no statistically significant dose relationship (Table 3 ).

After s.c. administration, statistically significant increases in serum $1,25(\mathrm{OH})_{2} \mathrm{D}$ levels occurred within the 0.3 - to $1-\mathrm{mg} / \mathrm{kg}$ dose range compared with those observed with placebo $(P<0.01$; Table 4). The maximum mean serum $1,25(\mathrm{OH})_{2} \mathrm{D}$ level occurred on day 4 , and increases from baseline were evident through day 15 at the 0.3 - and $0.6-\mathrm{mg} / \mathrm{kg}$ doses and through day 29 at the highest dose $(1 \mathrm{mg} / \mathrm{kg})$ (Figure 2F).

Other biochemical outcomes. For both i.v. and s.c. groups, we noted no consistent trends in serum calcium levels at any dose level (Figure 3, A and B). We found that 24-hour urine calcium excretion was extremely variable among patients (Figure 3, C and D), as an 
Table 2

Summary of ANOVA for PD parameters following i.v. administration of KRN23

\begin{tabular}{|c|c|c|c|c|c|}
\hline Parameters & $\begin{array}{l}\text { Dose level } \\
(\mathrm{mg} / \mathrm{kg})\end{array}$ & $\begin{array}{l}\text { Treatment response } \\
\text { vs. placebo response }{ }^{A}\end{array}$ & $\begin{array}{l}\text { Lower limit } \\
\text { of } 95 \% \mathrm{Cl}\end{array}$ & $\begin{array}{l}\text { Upper limit } \\
\text { of } 95 \% \mathrm{Cl}\end{array}$ & $\begin{array}{c}P \text { value } \\
\text { (pairwise comparison) }\end{array}$ \\
\hline TmP/GFR, mg/dl & $\begin{array}{c}0.003 \\
0.01 \\
0.03 \\
0.1 \\
0.3\end{array}$ & $\begin{array}{c}-0.32^{\mathrm{B}} \\
0.19 \\
0.50 \\
0.67 \\
1.44\end{array}$ & $\begin{array}{c}-0.67 \\
-0.19 \\
0.14 \\
0.36 \\
1.11\end{array}$ & $\begin{array}{l}0.04 \\
0.56 \\
0.86 \\
0.98 \\
1.77\end{array}$ & $\begin{array}{c}0.082 \\
0.325 \\
0.006^{\mathrm{C}} \\
<0.001^{\mathrm{C}} \\
<0.001^{\mathrm{C}}\end{array}$ \\
\hline Serum Pi, mg/dl & $\begin{array}{c}0.003 \\
0.01 \\
0.03 \\
0.1 \\
0.3\end{array}$ & $\begin{array}{l}-0.24^{\mathrm{B}} \\
-0.20^{\mathrm{B}} \\
-0.19^{\mathrm{B}} \\
0.25 \\
0.21\end{array}$ & $\begin{array}{c}-0.41 \\
-0.37 \\
-0.35 \\
0.11 \\
0.05\end{array}$ & $\begin{array}{c}-0.08 \\
-0.04 \\
-0.02 \\
0.39 \\
0.36\end{array}$ & $\begin{array}{c}0.004^{C} \\
0.015^{C} \\
0.024 \mathrm{C} \\
<0.001^{C} \\
0.009^{C}\end{array}$ \\
\hline Serum $1,25(\mathrm{OH})_{2} \mathrm{D}, \mathrm{pg} / \mathrm{ml}$ & $\begin{array}{c}0.003 \\
0.01 \\
0.03 \\
0.1 \\
0.3\end{array}$ & $\begin{array}{l}4.98 \\
14.2 \\
21.4 \\
20.6 \\
43.8\end{array}$ & $\begin{array}{c}-6.63 \\
2.61 \\
9.82 \\
10.8 \\
32.7\end{array}$ & $\begin{array}{l}16.60 \\
25.8 \\
33.0 \\
30.4 \\
54.9\end{array}$ & $\begin{array}{c}0.399 \\
0.017^{C} \\
<0.001^{C} \\
<0.001^{C} \\
<0.001^{C}\end{array}$ \\
\hline Serum calcium, mg/dl & $\begin{array}{c}0.003 \\
0.01 \\
0.03 \\
0.1 \\
0.3\end{array}$ & $\begin{array}{c}0.07 \\
0.14 \\
-0.02^{\mathrm{B}} \\
0.10 \\
-0.01^{\mathrm{B}}\end{array}$ & $\begin{array}{c}-0.04 \\
0.02 \\
-0.13 \\
0.00 \\
-0.12\end{array}$ & $\begin{array}{l}0.19 \\
0.26 \\
0.10 \\
0.20 \\
0.10\end{array}$ & $\begin{array}{l}0.206 \\
0.017 c \\
0.782 \\
0.040^{C} \\
0.818\end{array}$ \\
\hline 24-hour urine calcium, mg & $\begin{array}{c}0.003 \\
0.01 \\
0.03 \\
0.1 \\
0.3\end{array}$ & $\begin{array}{l}58.7 \\
77.2 \\
76.1 \\
87.9 \\
74.8\end{array}$ & $\begin{array}{c}-3.14 \\
23.3 \\
22.2 \\
42.5 \\
23.6\end{array}$ & $\begin{array}{l}120.5 \\
131.1 \\
130.0 \\
133.4 \\
126.1\end{array}$ & $\begin{array}{c}0.063 \\
0.006^{\mathrm{C}} \\
0.006^{\mathrm{C}} \\
<0.001^{\mathrm{C}} \\
0.005^{\mathrm{C}}\end{array}$ \\
\hline 2-hour urine calcium/creatinine, $\mathrm{mg} / \mathrm{mg}$ & $\begin{array}{c}0.003 \\
0.01 \\
0.03 \\
0.1 \\
0.3\end{array}$ & $\begin{array}{c}0.07 \\
-0.01^{\mathrm{B}} \\
-0.17^{\mathrm{B}} \\
0.16 \\
0.01\end{array}$ & $\begin{array}{c}-0.10 \\
-0.18 \\
-0.34 \\
0.03 \\
-0.17\end{array}$ & $\begin{array}{l}0.25 \\
0.17 \\
0.00 \\
0.32 \\
0.19\end{array}$ & $\begin{array}{l}0.421 \\
0.938 \\
0.054 \\
0.017 \mathrm{c} \\
0.926\end{array}$ \\
\hline
\end{tabular}

ALeast squares mean difference in change from baseline between active and placebo treatment calculated from ANOVA model with dose and visit as explanatory variables. ${ }^{B}$ Negative values indicate a decrease. ${ }^{C} P<0.05$.

increase was noted after i.v. dosing (0.01-0.3 mg/kg, $P \leq 0.006$; Table $2)$, but not after s.c. dosing, except at the lowest dose $(0.1 \mathrm{mg} / \mathrm{kg}$, $P=0.004$; Table 4). It is doubtful that these statistical differences represent a drug effect, as we detected no dose relationship, and these differences were confounded by a relatively high baseline value in the placebo group. When ANOVA testing was performed to determine the difference between active and placebo treatments at each time point after dosing, we observed no significant difference $(P>0.05)$. No patient excreted more than $400 \mathrm{mg}$ of calcium per 24 hours after KRN23 administration. The fasting 2-hour urine calcium/creatinine ratio did not show dose-related increases with KRN23 i.v. or s.c. dosing (Tables 2 and 4); this ratio was greater than the upper limit of normal $(0.22 \mathrm{mg} / \mathrm{mg})(12)$ only when baseline values were also greater than $0.22 \mathrm{mg} / \mathrm{mg}$. For both i.v. and s.c. groups, we noted no consistent trends at different dose levels for serum iPTH, BALP, or creatinine, despite a $P$ value of less than 0.05 for some doses (Supplemental Figures 1 and 2 and Supplemental Tables 1 and 2; supplemental material available online with this article; doi:10.1172/JCI72829DS1). Mild decreases were evident for $25(\mathrm{OH}) \mathrm{D}$, though they were of questionable clinical significance.

Table 3

$\mathrm{AUC}_{\text {last }}$ for PD parameters following i.v. administration of KRN23

\begin{tabular}{lcccccc} 
i.v. Dose $\mathbf{m g} / \mathbf{k g}$ & $\mathbf{0 . 0 0 3}$ & $\mathbf{0 . 0 1}$ & $\mathbf{0 . 0 3}$ & $\mathbf{0 . 1}$ & $\mathbf{0 . 3}$ & $\mathbf{9 5 \%} \mathbf{C l}$ for slope $\beta^{\mathrm{A}}$ \\
No. of patients & 3 & 3 & 3 & 5 & 3 & {$[0.1032,0.2889]$} \\
TmP/GFR, $\mathrm{mg} \times$ day/dl & $42.1 \pm 9.6$ & $45.4 \pm 10.9$ & $42.0 \pm 12.7$ & $70.1 \pm 13.6$ & $106.2 \pm 28.4$ & {$[0.4$} \\
Serum Pi, $\mathrm{mg} \times$ day/dl & $1.46 \pm 1.06$ & $3.89 \pm 5.36$ & $6.36 \pm 7.14$ & $25.7 \pm 20.8$ & $23.7 \pm 12.8$ & {$[0.4071,1.1039]$} \\
Serum $1,25(\mathrm{OH})_{2} \mathrm{D}, \mathrm{pg} \times$ day/ml & $78.6 \pm 68.5$ & $123.2 \pm 24.9$ & $398.4 \pm 425.2$ & $496.1 \pm 469.2$ & $1160.8 \pm 304.5$ & {$[0.334,0.8837]$} \\
\hline
\end{tabular}

AFull range of doses were used in power model analysis. 

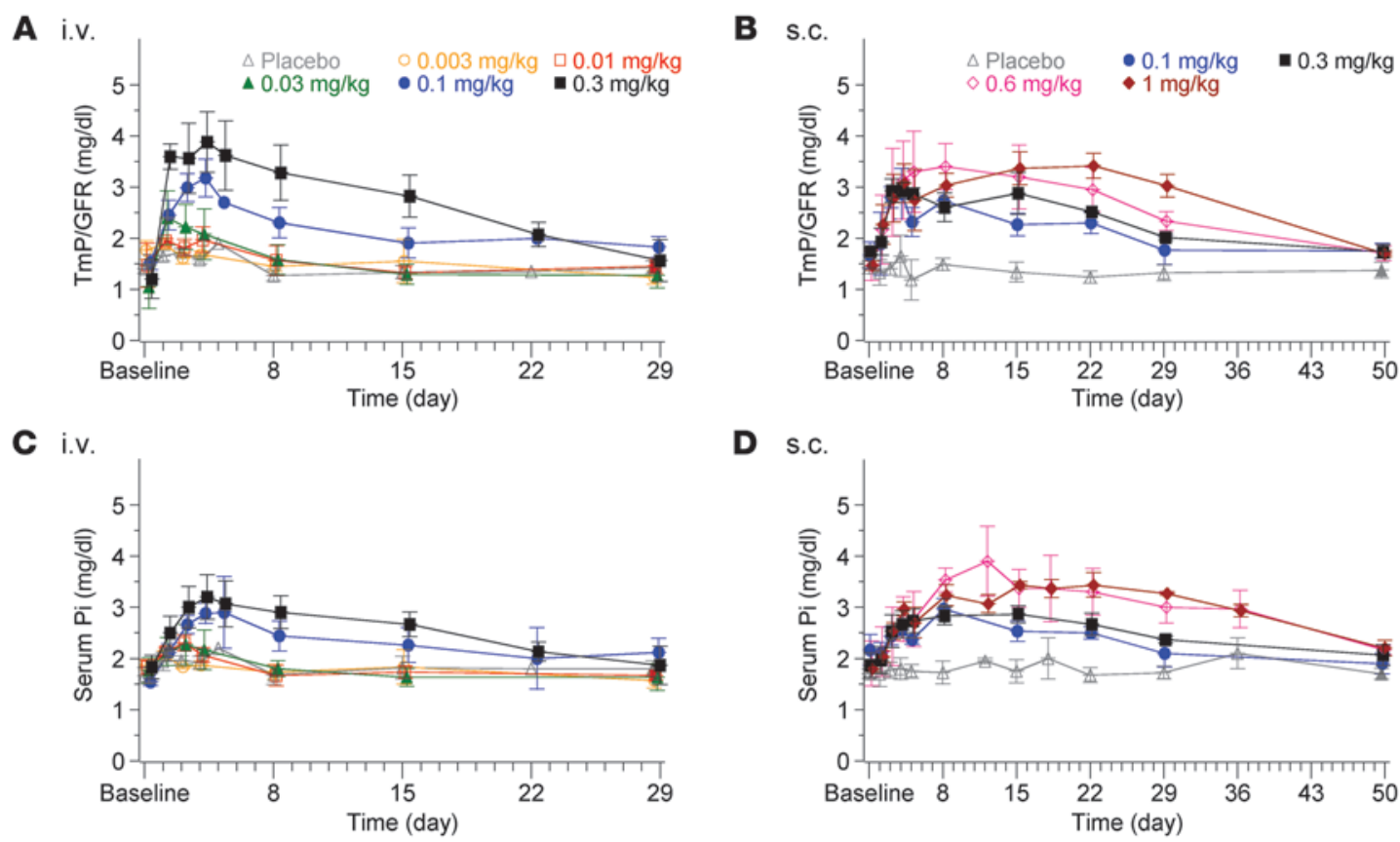

D s.c.
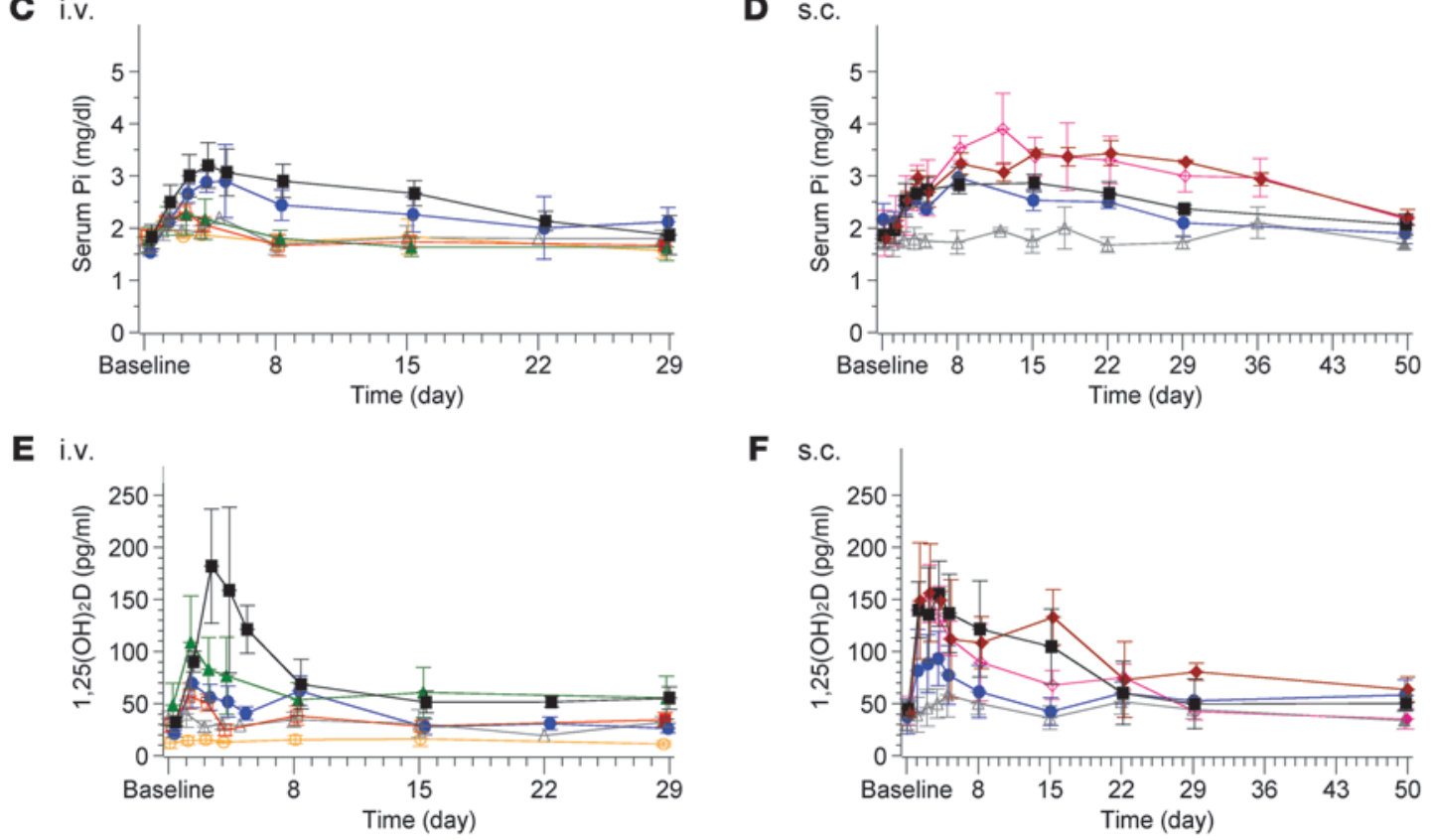

Figure 2

Effect of i.v. and s.c administration of KRN23 on TmP/GFR, serum Pi, and 1,25(OH) 2 D compared with placebo. (A and B) TmP/GFR; (C and D) serum $\mathrm{Pi}$; and (E and F) 1,25(OH) $)_{2}$ D. For the i.v. cohorts, six profiles are shown for panels A, C, and E: placebo (gray), 0.003 (yellow), 0.01 (red), 0.03 (green), 0.1 (blue), and $0.3 \mathrm{mg} / \mathrm{kg}$ (black). For s.c. cohorts, five profiles are shown for panels B, D, and F: placebo (gray), 0.1 (blue), 0.3 (black), 0.6 (pink), and $1 \mathrm{mg} / \mathrm{kg}$ (brown). Data are presented as the mean $\pm \mathrm{SEM}$.

$P K / P D$ analysis. The mean serum concentration-time profiles following i.v. and s.c. administration are shown in Figure 4, A and B, respectively. Following i.v. administration, the mean time to reach the maximum serum concentration $\left(\mathrm{T}_{\max }\right)$ occurred between 1 and 2 hours, and the mean $\mathrm{t}_{1 / 2}$ of KRN23 ranged from 180 to 296 hours (8-12 days) for doses between 0.01 and $0.3 \mathrm{mg} / \mathrm{kg}$ (Table 6). With i.v. KRN23 dosing, the AUC from time 0 to infinity ( $\left.\mathrm{AUC}_{\text {inf }}\right)$ increased as the dose increased from 0.01 to $0.3 \mathrm{mg} / \mathrm{kg}$ (Table 6). Following s.c. administration, the mean $\mathrm{T}_{\max }$ occurred between 192 and 272 hours (8-11 days), and the mean $t_{1 / 2}$ ranged from 322 to 448 hours (13-19 days) for the 0.1 - to $1-\mathrm{mg} / \mathrm{kg}$ dose groups. With s.c. dosing, the

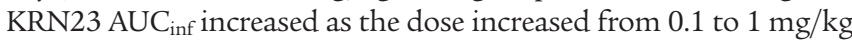
(Table 6). The bioavailability of KRN23 following s.c. administration was essentially complete based on the comparability of the $\mathrm{AUC}_{\mathrm{inf}}$ following i.v. and s.c. administration of 0.1- and $0.3-\mathrm{mg} / \mathrm{kg}$ doses.

With i.v. dosing, we found that maximum concentrations of KRN23 were reached between 1 and 2 hours for all doses (Figure $4 \mathrm{~A}$ ), whereas serum Pi reached the maximum observed serum concentration $\left(\mathrm{C}_{\max }\right)$ at different times for different doses (Figure 2C).
Specifically, the $C_{\max }$ for serum Pi was attained at $12,48,48,72$ to 96 , and 72 hours, respectively, for the 0.003-, 0.01-, 0.03-, 0.1-, and $0.3-\mathrm{mg} / \mathrm{kg}$ doses (Figure 2C). Thus, there was a delayed effect of KRN23 on the maximum response in serum Pi following i.v. dosing. In contrast, s.c. administration of KRN23 resulted in commensurate increases in serum Pi and KRN23 concentrations (Figure 4B and Figure 2D). The mean serum Pi and KRN23 reached maximum concentrations at approximately the same time (days 8-15 for 0.1 - and $0.3-\mathrm{mg} / \mathrm{kg}$ dose groups and by day 12 for the $0.6-\mathrm{mg} / \mathrm{kg}$ dose group) (Figure 4B and Figure 2D). Thus, serum Pi increased consistently as the KRN23 concentration increased.

We found that the $\mathrm{AUC}_{\text {last }}$ for $\mathrm{TmP} / \mathrm{GFR}$, serum $\mathrm{Pi}$, and $1,25(\mathrm{OH})_{2} \mathrm{D}$ following administration of KRN23 was linearly correlated with the $\mathrm{AUC}_{\text {inf }}$ for $\mathrm{KRN} 23(r=0.76,0.74$, and 0.34 , respectively) (Figure 5, A-C, respectively).

Baseline intact FGF23 levels were not predictive of increases from baseline in serum Pi, as shown by a lack of correlation between baseline intact FGF23 levels and the dose-normalized $\mathrm{AUC}_{\text {last }}$ for the change in serum Pi from baseline $(r=0.011)$. 
Table 4

Summary of ANOVA for PD parameters following s.c. administration of KRN23

\begin{tabular}{|c|c|c|c|c|c|}
\hline Parameters & $\begin{array}{c}\text { Dose level } \\
\text { (mg/kg) }\end{array}$ & $\begin{array}{c}\text { Treatment response } \\
\text { vs. placebo response }{ }^{A}\end{array}$ & $\begin{array}{l}\text { Lower limit } \\
\text { of } 95 \% \mathrm{Cl}\end{array}$ & $\begin{array}{l}\text { Upper limit } \\
\text { of } 95 \% \mathrm{Cl}\end{array}$ & $\begin{array}{c}P \text { value } \\
\text { (pairwise comparison) }\end{array}$ \\
\hline TmP/GFR, mg/dl & $\begin{array}{c}0.1 \\
0.3 \\
0.6 \\
1\end{array}$ & $\begin{array}{l}0.62 \\
0.73 \\
1.24 \\
1.25\end{array}$ & $\begin{array}{c}0.38 \\
0.49 \\
1.0 \\
1.00\end{array}$ & $\begin{array}{c}0.86 \\
0.97 \\
1.5 \\
1.49\end{array}$ & $\begin{array}{l}<0.001^{\mathrm{C}} \\
<0.001^{\mathrm{C}} \\
<0.001^{\mathrm{C}} \\
<0.001^{\mathrm{C}}\end{array}$ \\
\hline Serum Pi, mg/dl & $\begin{array}{c}0.1 \\
0.3 \\
0.6 \\
1\end{array}$ & $\begin{array}{l}0.12 \\
0.44 \\
0.70 \\
0.79\end{array}$ & $\begin{array}{c}-0.06 \\
0.27 \\
0.53 \\
0.62\end{array}$ & $\begin{array}{l}0.30 \\
0.62 \\
0.87 \\
0.95\end{array}$ & $\begin{array}{l}0.177 \\
<0.001^{C} \\
<0.001^{C} \\
<0.001^{C}\end{array}$ \\
\hline Serum $1,25(\mathrm{OH})_{2} \mathrm{D}, \mathrm{pg} / \mathrm{ml}$ & $\begin{array}{c}0.1 \\
0.3 \\
0.6 \\
1\end{array}$ & $\begin{array}{l}9.70 \\
29.0 \\
20.6 \\
41.7\end{array}$ & $\begin{array}{c}-5.63 \\
13.6 \\
5.2 \\
26.4\end{array}$ & $\begin{array}{c}25.03 \\
44.3 \\
35.9 \\
57.1\end{array}$ & $\begin{array}{c}0.214 \\
<0.001^{C} \\
0.009^{C} \\
<0.001^{C}\end{array}$ \\
\hline Serum calcium, mg/dl & $\begin{array}{c}0.1 \\
0.3 \\
0.6 \\
1\end{array}$ & $\begin{array}{l}-0.02^{\mathrm{B}} \\
0.02^{\mathrm{B}} \\
-0.01^{\mathrm{B}} \\
-0.05^{\mathrm{B}}\end{array}$ & $\begin{array}{l}-0.14 \\
-0.09 \\
-0.12 \\
-0.16\end{array}$ & $\begin{array}{l}0.10 \\
0.14 \\
0.10 \\
0.06\end{array}$ & $\begin{array}{l}0.744 \\
0.690 \\
0.850 \\
0.337\end{array}$ \\
\hline 24-hour urine calcium, mg & $\begin{array}{c}0.1 \\
0.3 \\
0.6 \\
1\end{array}$ & $\begin{array}{c}36.82 \\
11.00 \\
10.69 \\
6.71\end{array}$ & $\begin{array}{c}12.34 \\
-13.49 \\
-10.53 \\
-14.51\end{array}$ & $\begin{array}{l}61.31 \\
35.49 \\
31.91 \\
27.92\end{array}$ & $\begin{array}{l}0.004 \mathrm{C} \\
0.375 \\
0.320 \\
0.532\end{array}$ \\
\hline 2-hour urine calcium/creatinine, $\mathrm{mg} / \mathrm{mg}$ & $\begin{array}{c}0.1 \\
0.3 \\
0.6 \\
1\end{array}$ & $\begin{array}{l}-0.06^{\mathrm{B}} \\
0.00 \\
0.03 \\
0.00\end{array}$ & $\begin{array}{l}-0.09 \\
-0.02 \\
0.01 \\
-0.0\end{array}$ & $\begin{array}{c}-0.04 \\
0.03 \\
0.05 \\
0.03\end{array}$ & $\begin{array}{c}<0.001^{C} \\
0.747 \\
0.015^{C} \\
0.749\end{array}$ \\
\hline
\end{tabular}

ALeast squares mean difference in change from baseline (CFB) between active and placebo treatment calculated from ANOVA model with dose and visit as explanatory variables. ${ }^{B}$ Negative values indicate a decrease. ${ }^{C} P<0.05$.

Safety and adverse events. In both the i.v. and s.c. groups, we observed a higher frequency of adverse events (AEs) in patients receiving KRN23 (82\% for i.v., 83\% for s.c.) compared with those receiving placebo ( $40 \%$ for i.v., $50 \%$ for s.c.). The most common AEs were nausea $(24 \%)$ and headache $(18 \%)$ in the i.v. group and elevated serum amylase and back pain in the s.c. group (17\% each). Six patients experienced AEs that were considered by the investigator to be related to the study drug (4 patients in the i.v. dose groups [24\%] and 2 patients in the s.c. dose groups [17\%]): these included nausea (12\%, 2 patients), dizziness, dysgeusia, headache, and blood pressure increases $(6 \%, 1$ patient each) in the i.v. group and blood amylase increases (17\%, 2 patients) in the s.c. group. There were no serious AEs, deaths, or AEs that led to withdrawal from the study. Single-dose administration was well tolerated in both the i.v. and s.c. cohorts based on reported AEs, hematology and blood chemis- try laboratory values, vital signs, measures of calcium homeostasis, renal ultrasonography, and ECGs. No patient had an increase in nephrocalcinosis or developed hypercalciuria, hypercalcemia, or a rise in serum iPTH or creatinine. We detected no anti-KRN23 antibody in any of the patients and observed no hypersensitivity or infusion reaction after either s.c. or i.v. administration.

\section{Discussion}

$\mathrm{XLH}$ is a prototypical chronic disorder of renal phosphate wasting and the most common form of heritable rickets/osteomalacia. Current therapies are significantly limited, and there have been no meaningful treatment advances for several decades (9).

This first-in-human, single-dose, phase I study in adult patients with XLH demonstrated increases in TmP/GFR after i.v. or s.c. administration of KRN23, a human anti-FGF23 anti-

\section{Table 5}

$A U C_{\text {last }}$ for PD parameters following s.c. administration of KRN23

$\begin{array}{lccccc}\text { s.c. Dose } \mathbf{m g} / \mathbf{k g} & \mathbf{0 . 1} & \mathbf{0 . 3} & \mathbf{0 . 6} & \mathbf{1} & \mathbf{9} \% \mathbf{C l} \text { for slope } \beta^{\mathrm{A}} \\ \mathbf{N} & \mathbf{3} & \mathbf{3} & \mathbf{3} & \mathbf{3} & \mathbf{9 5} \\ \mathrm{TmP} / \mathrm{GFR}, \mathrm{mg} \times \mathrm{d} / \mathrm{dl} & 103.6 \pm 18.0 & 113.7 \pm 6.85 & 127.8 \pm 28.2 & 138.3 \pm 13.1 & {[0.02399,0.2306]} \\ \text { Serum } \mathrm{Pi}, \mathrm{mg} \times \mathrm{d} / \mathrm{dl} & 20.6 \pm 16.8 & 20.0 \pm 11.8 & 68.1 \pm 37.1 & 58.14 \pm 13.0 & {[0.1122,1.1343]} \\ \text { Serum } 1,25(\mathrm{OH}){ }_{2} \mathrm{D}, \mathrm{pg} \times \mathrm{d} / \mathrm{ml} & 535 \pm 621 & 1,385 \pm 1104 & 613 \pm 413 & 533 \pm 1,274 & \mathrm{NA}\end{array}$


A i.v.

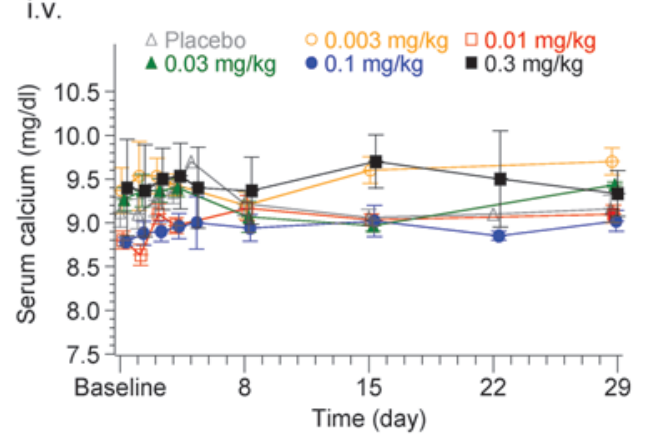

C i.v.

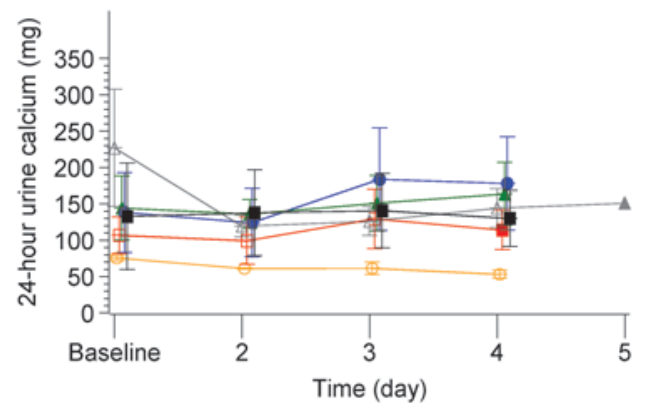

B

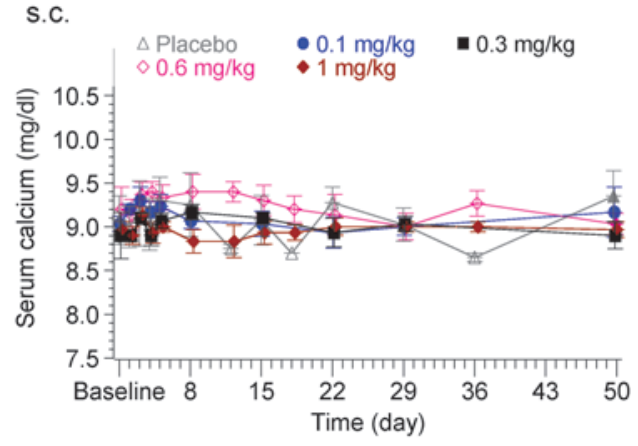

D s.c.

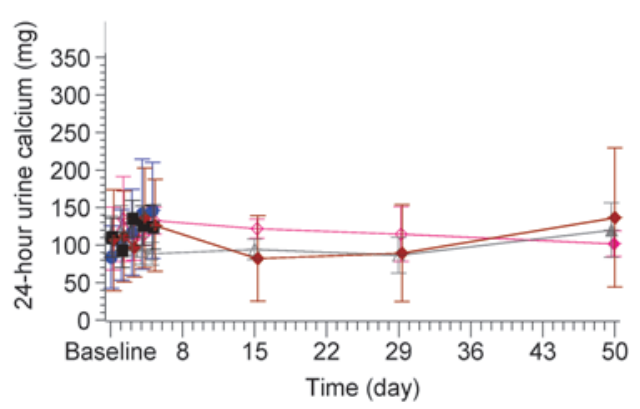

\section{Figure 3}

Effect of i.v. and s.c administration of KRN23 on serum calcium and 24-hour urine calcium compared with placebo. (A and B) Serum calcium; (C and D) 24-hour urine calcium. For i.v. cohorts, six profiles are shown for panels A and C: placebo (gray), 0.003 (yellow), 0.01 (red), 0.03 (green), 0.1 (blue), and $0.3 \mathrm{mg} / \mathrm{kg}$ (black). For s.c. cohorts, five profiles are shown in panels B and D: placebo (gray), 0.1 (blue), 0.3 (black), 0.6 (pink), and $1 \mathrm{mg} / \mathrm{kg}$ (brown). Data are presented as the mean \pm SEM.

body, resulting in clinically relevant increases in serum Pi concentrations. We found that accompanying increases in serum $1,25(\mathrm{OH})_{2} \mathrm{D}$ also occurred. The magnitude and duration of responses were dose related with both modes of administration, and s.c. dosing resulted in a longer duration of action than with i.v. dosing. The persistence of these effects for at least 28 days after receiving KRN23 suggests that once-monthly treatment via the s.c. route may be an effective therapeutic approach for patients with XLH. Although serum $1,25(\mathrm{OH})_{2} \mathrm{D}$ levels increased, we observed no significant elevations in serum calcium levels, 24-hour urine calcium excretion, or the fasting 2-hour urine calcium/creatinine ratio. Despite being generally lower than with the s.c. doses, after most i.v. doses, an increase in 24-hour urine calcium levels (as compared with changes from baseline in the placebo cohort) was evident. This finding did not persist at the higher s.c. doses, suggesting that this was due to subject variability in calcium excretion, specifically as demonstrated by the high baseline value in the i.v. placebo group. We observed no differences when we examined the comparison of each dose with placebo, rather than comparing the change from baseline versus that of placebo. These findings, together with the absence of significant changes in renal mineral deposits on ultrasound examination, provide reassurance that a single dose of KRN23 does not cause complications from increased intestinal calcium absorption in the face of increased $1,25(\mathrm{OH})_{2} \mathrm{D}$ and serum phosphate. Furthermore, we observed no increase in serum iPTH, indicating that the hyperparathyroidism that occurs in XLH was not exacerbated. KRN23 did not result in any serious medical sequelae and was well tolerated as a single dose when given either i.v. or s.c. to this sample of adult patients with XLH. We observed no infusion reactions or antibodies in response to this human monoclonal antibody.

The extended duration of action and near-complete absorption of KRN23 after s.c. administration, combined with the comparable PK exposure observed with s.c. and i.v. dosing, support the practicality of a once-monthly s.c. formulation in clinical use. After s.c. KRN23 administration, serum Pi and KRN23 peaked simultaneously between days 8 and 15, whereas, following i.v. administration, peak serum Pi was substantially delayed with respect to peak KRN23 concentrations at 1 to 2 hours. The differences in the PK-PD relationship between s.c. and i.v. administration are likely related to slow absorption from the s.c. depot, thereby allowing adequate time for the inhibition of FGF23 signaling to impact downstream gene expression. The comparatively rapid attainment of peak KRN23 concentrations after i.v. administration contrast accordingly with the longer time frame required to observe resultant changes in the measured physiologic outcome (serum Pi) following s.c. administration. The $\mathrm{t}_{1 / 2}$ of 13 to 19 days for s.c. administered KRN23 at 0.1 - to $1-\mathrm{mg} / \mathrm{kg}$ doses supports the notion that s.c. KRN23 may be effective when administered monthly, thereby offering a considerably more convenient approach than the use of oral phosphate and calcitriol regimens, which require dosing 3-4 times daily (9), a schedule that necessarily challenges compliance, particularly in children.

Our study translates the previous work in Hyp mice, an animal model of XLH caused by mutations in murine Phex, to humans. A single dose of murine anti-FGF23 corrected hypophosphatemia and increased serum $1,25(\mathrm{OH})_{2} \mathrm{D}$, with concomitant increases in 

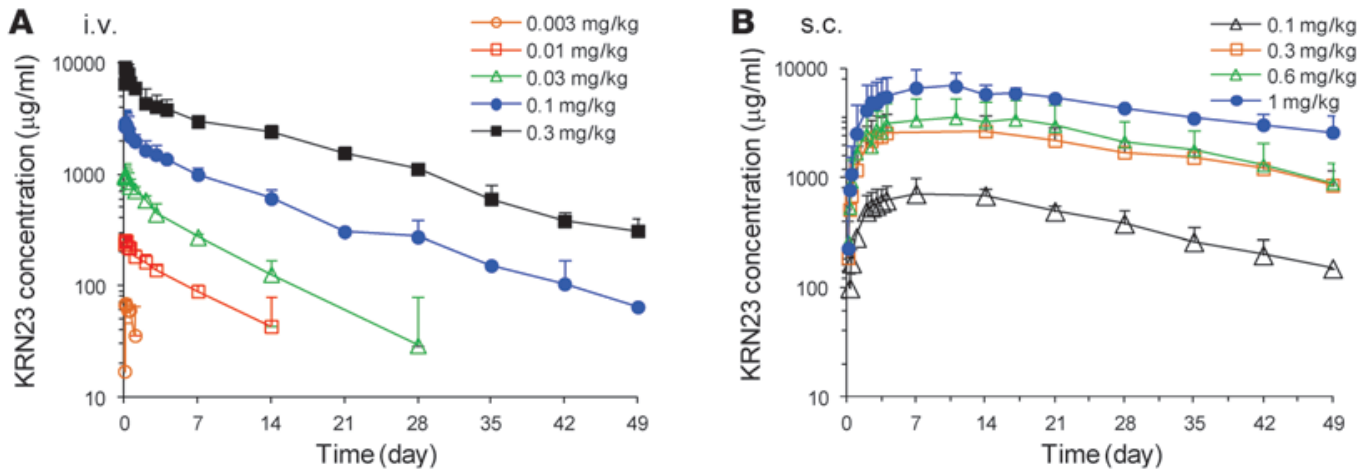

\section{Figure 4}

KRN23 PK profiles following single-dose administration. (A) Single-dose i.v. administration of 0.003 (orange), 0.01 (red), 0.03 (green), 0.1 (blue), and 0.3 (black) mg/kg of KRN23; (B) Single-dose s.c. administration of 0.1 (black), 0.3 (orange), 0.6 (green), and $1 \mathrm{mg} / \mathrm{kg}$ (blue) of KRN23. Data are presented as the mean \pm SD.

renal expression of the type IIa sodium-phosphate cotransporter and 1- $\alpha$-hydroxylase and decreases in expression of vitamin D 24-hydroxylase (11). Importantly, amelioration of rachitic bone was evident after repeated dosing in mice $(11,13)$. Long-term clinical studies will be an important next step to assess skeletal outcomes and safety of chronic dosing, particularly with respect to metastatic calcification in the kidney and cardiovascular system that occurs with current regimens using calcitriol and oral phosphate supplements $(9,14)$. We conclude that KRN23 effectively increases TmP/GFR, serum $\mathrm{Pi}$, and $1,25(\mathrm{OH})_{2} \mathrm{D}$ following singledose administration to adults with XLH. Since hypophosphatemia is generally considered the major etiological factor causing rickets and osteomalacia in XLH, the positive effects on biochemistry and the favorable safety profile of KRN23 suggest a potential utility for KRN23 treatment in adults and children with XLH.

\section{Methods}

Patients. Adults with a clinical diagnosis of XLH from four sites in the United States were eligible to participate in this phase I, double-blind, randomized, placebo-controlled, single-dose, dose-escalation study of KRN23 administered i.v. or s.c. Informed consent was obtained from all patients. Patients were screened within a 30-day window before the dosing day. Inclusion criteria included age greater than or equal to 18 years, a clinical diagnosis of XLH as documented by the investigator, intact serum FGF23 greater than or equal to $30 \mathrm{pg} / \mathrm{ml}$, a TmP/GFR less than $2.0 \mathrm{mg} / \mathrm{dl}$ at screening, a
GFR greater than $60 \mathrm{ml} /$ minute, serum calcium levels less than $10.8 \mathrm{mg} / \mathrm{dl}$, and a willingness to use contraception during the study. Key exclusion criteria were: pregnancy or lactation; history of recent major surgery; receipt of a monoclonal antibody or of a live (attenuated) vaccine within 3 months before screening; positive HIV or hepatitis B or C tests; history of allergic reaction to a monoclonal antibody; immunodeficiency or predisposition to infection or use of antibiotics within 3 weeks before screening; participation in another trial for a drug or device within 30 days or five half-lives of the drug prior to screening; and other conditions or abnormal test results likely to affect safety or data interpretation. No patient received vitamin D or vitamin D analogs, calcium or phosphate supplements, calcimimetics, or aluminum hydroxide antacids from 10 days before screening through the end of the study. Patients were allowed to continue any medications administered prior to study participation at the discretion of an investigator.

Study design. At each dose level for both i.v. and s.c. treatment groups, 4 patients were randomized in a 3:1 manner to receive a single dose of either KRN23 or placebo. Each patient received only one injection of either KRN23 or placebo. Sequential dose escalation occurred in the i.v. (0.003, $0.01,0.03,0.1$, and $0.3 \mathrm{mg} / \mathrm{kg}$ ) and s.c. $(0.1,0.3,0.6$, and $1 \mathrm{mg} / \mathrm{kg})$ groups. Patients were monitored as inpatients in clinical research units from 2 days before dosing (day -2) to 4 or 5 days after dosing and were evaluated at scheduled outpatient visits on days 8, 12, 15, 18, 22, and 29 in the i.v. and s.c. treatment groups and additionally on days 36,43 , and 50 for patients in the s.c. group. KRN23 or placebo was administered to all patients the morning after an overnight fast.

Table 6

Summary of KRN23 PK parameters

$\begin{array}{lccccc}\text { Dose (mg/kg) (route) } & \mathbf{N} & \mathbf{T}_{\max }(\mathbf{h}) & \mathbf{C}_{\max }(\mu \mathbf{g} / \mathbf{m l}) & \text { AUC }_{\text {inf }}(\mu \mathbf{g} \times \mathbf{h} / \mathbf{m l}) & \mathbf{t}_{1 / 2}(\mathbf{h}) \\ 0.003 \text { (i.v.) } & 3 & 1.8 \pm 0.6 & 0.07 \pm 0.01 & - & - \\ 0.01 \text { (i.v.) } & 3 & 1.5 \pm 0.6 & 0.26 \pm 0.02 & 52 \pm 15 & 199 \pm 84 \\ 0.03 \text { (i.v.) } & 3 & 1.2 \pm 1.0 & 1.04 \pm 0.20 & 156 \pm 29 & 180 \pm 99 \\ 0.1 \text { (i.v.) } & 5 & 1.2 \pm 0.7 & 2.95 \pm 0.93 & 666 \pm 144 & 296 \pm 66 \\ 0.3 \text { (i.v.) } & 3 & 1.2 \pm 0.0 & 9.20 \pm 1.83 & 2170 \pm 312 & 273 \pm 29 \\ 0.1 \text { (s.c.) } & 3 & 271 \pm 91 & 0.76 \pm 0.27 & 599 \pm 157 & 423 \pm 119 \\ 0.3 \text { (s.c.) } & 3 & 192 \pm 110 & 3.0 \pm 1.0 & 2780 \pm \mathrm{NC} & 362 \pm \mathrm{NC} \\ 0.6 \text { (s.c.) } & 3 & 216 \pm 42 & 3.6 \pm 1.9 & 3180 \pm 1680 & 322 \pm 41 \\ 1 \text { (s.C.) } & 3 & 272 \pm 124 & 7.7 \pm 2.1 & 6900 \pm \mathrm{NC} & 448 \pm \mathrm{NC}\end{array}$

The mean $\pm S D$ is presented. - , not calculated because $t_{1 / 2}$ could not be estimated; NC, samples from only 2 subjects were available, and $S D$ was not calculated. 


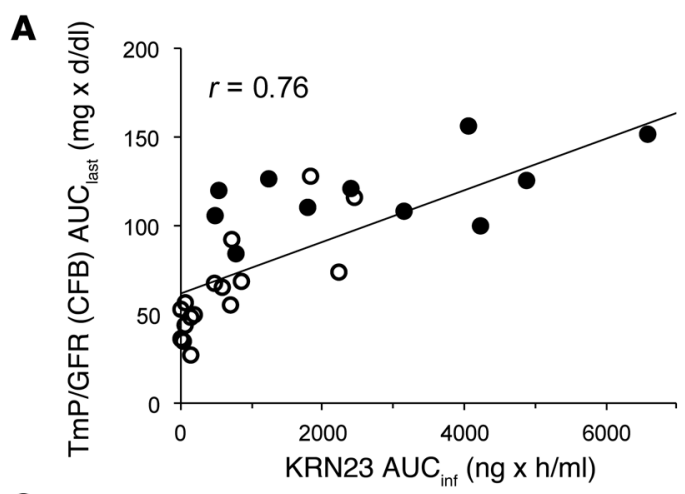

C

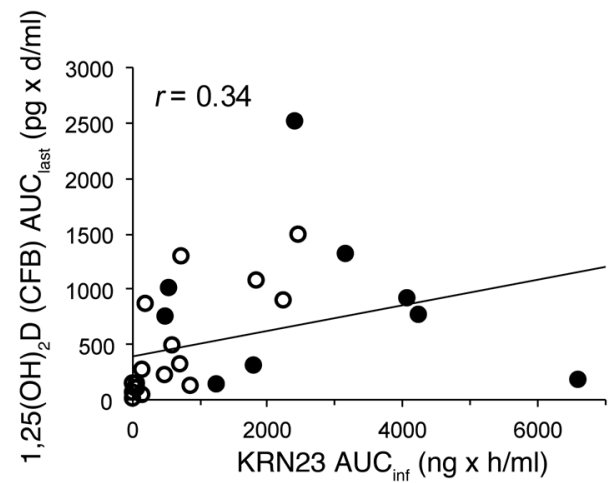

$\mathbf{B}$ ิ

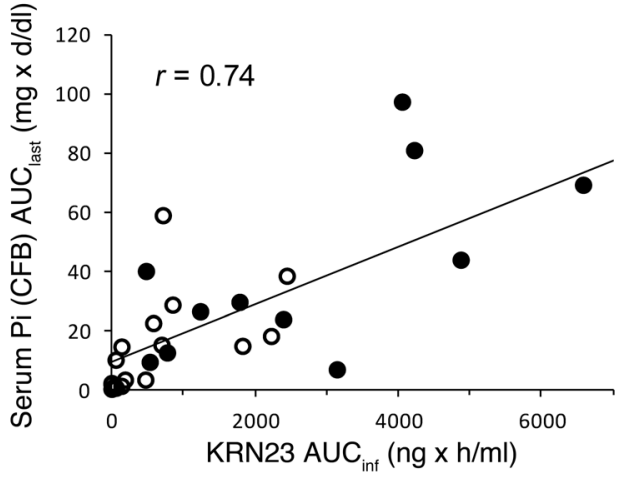

Figure 5

Relationship between PK and PD parameters. (A) TmP/GFR change from baseline (CFB) AUC last; (B) serum Pi (CFB) $\mathrm{AUC}_{\text {last }}$; and (C) 1,25(OH) ${ }_{2} \mathrm{D}(\mathrm{CFB})$ $A \cup C_{\text {last. }}$ Open circles indicate i.v. dosing, and closed circles indicate s.c. dosing. The regression line is shown. Note: 2 patients (one at $0.1 \mathrm{mg} / \mathrm{kg}$ and one at $1 \mathrm{mg} / \mathrm{kg}$ ) with a negative $\mathrm{AUC}_{\text {last }}$ in panel $\mathbf{C}$ are not shown in the plot, but are included in the regression calculation.
Block randomization with interactive voice response system (IVRS) was used (Theradex). The patients, investigator, and other site personnel except the pharmacist were blinded to the treatment assignment. The treatment could not be distinguished because both KRN23 and placebo were clear and colorless. The unblinded pharmacist prepared all treatments based on randomization from the IVRS. The unblinded pharmacist was responsible for securing the randomization list and any unblinded pharmacy records in a private location.

Intravenous dosing occurred over a 10-minute period with an infusion pump, and s.c. injections were administered via the abdominal wall. All patients were served a standardized diet formulated to provide a daily intake of 800 to $1,000 \mathrm{mg}$ of phosphorus during the inpatient observation period. Patients were instructed to maintain their usual dietary intake and exercise regimens during the remainder of the study.

At each i.v. or s.c. dose level, the dosing of patients was staggered: a minimum observation period of 9 days was required between dosing the first and second patients and the second and third patients, and 2 days were required between the dosing of the third and fourth patients. Among parallel escalating dose cohorts, the dose escalation was also staggered. Once the fourth patient at each dose level reached day 15 , the Data Safety Review Committee determined the safety of escalation to the next dose level. Dose escalation was allowed if: (a) there were no dose-limiting or otherwise unacceptable toxicities; (b) no more than 1 patient had a serum Pi level greater than $4.5 \mathrm{mg} / \mathrm{dl}$ or experienced greater than or equal to grade 2 treatment-related toxicity as defined in the Common Toxicity Criteria guidelines (15); and (c) no patient developed a serum Pi level greater than $6.5 \mathrm{mg} / \mathrm{dl}$. Subcutaneous dosing began after an acceptable safety profile was established in the $0.1-\mathrm{mg} / \mathrm{kg}$ i.v. cohort. Two s.c. dose levels $(0.1$ and $0.3 \mathrm{mg} / \mathrm{kg}$ ) were first tested as i.v. doses, and for these two s.c. dose levels, at least 2 days were required between dosing of each new patient. The higher s.c. dosing was staggered, as was the case for the i.v. dosing cohorts. The investigator at each center recorded all data in the case report forms, which were certified by the investigator's signature.
Investigational product. KRN23 was supplied as a sterile, clear, colorless, preservative-free solution in single-use $10-\mathrm{ml}$ vials containing $4 \mathrm{ml}$ of KRN23 $(8 \mathrm{mg})$ at a concentration of $2 \mathrm{mg} / \mathrm{ml}$, or 5 - $\mathrm{ml}$ vials containing $1 \mathrm{ml}$ of KRN23 $(10 \mathrm{mg})$ at a concentration of $10 \mathrm{mg} / \mathrm{ml}$. Placebo was provided as a sterile, clear, colorless, preservative-free solution in single-use 10 - $\mathrm{ml}$ vials containing $4 \mathrm{ml}$ of placebo. KRN23 and placebo were stored at $2^{\circ} \mathrm{C}$ to $8^{\circ} \mathrm{C}$. The KRN23 products were protected from light and were not frozen. The study drug was manufactured, labeled, and packaged by Kyowa Hakko Kirin Co., Ltd.

Study assessments. The results of safety-related biochemical testing, physical examination, ECG, and AE occurrences were monitored regularly from the screening visit to the end of the study. Height, weight, and age were recorded at the screening visit, and the patient's weight on the day prior to dosing was used to calculate the administered study drug dose. Renal ultrasonography was performed at screening and at the end of the study (day 29 or day 50), with interpretations provided by local radiologists. ECGs were recorded at baseline and on days 4 or 5, 15, 29, and/or 50 after dosing, and ECG intervals (QT, RR, QRS, and PR) were read at each site. $\mathrm{TmP} / \mathrm{GFR}$ was determined using the Walton and Bijvoet nomogram (16).

Patients were allowed only oral water intake after $10 \mathrm{pm}$ on the day before each morning blood and urine collection. Blood samples for biochemical and $\mathrm{PD}$ assessments were collected on day -1 , before dosing and $2,4,8$, and 12 hours after dosing on day 1 , and on days $2,3,4,5,8,12,15$, $18,22,29,36,43$, and 50 for the i.v. and s.c. cohorts. Blood for the determination of PK parameters was collected on day -1 , and on day 1 immediately after dosing and at 1, 2, 4, 8, and 12 hours, and on days 2, 3, 4, 5, 8, 15, 22, $29,36,43$, and 50 for the i.v. cohorts. For the s.c. cohorts, PK samples were collected on day -1 , and at $4,8,12,24,48,60,72$, and 84 hours after dosing, and on days $5,8,12,15,18,22,29,36,43$, and 50 . Blood samples for antiKRN23 antibody measurements were obtained on day -1 before dosing and on day 29 or day 50 after dosing. A fasting 2-hour urine sample was collected before dosing at each visit, together with a corresponding blood 
sample collected at the midpoint of the urine collection. Twenty-four-hour urine samples were collected on days $-1,1,2,3$, and 4 for the i.v. cohorts and on days $1,1,2,3,4,15,29$, and 50 for the s.c cohorts. Blood samples were processed, and serum samples were stored at $-70^{\circ} \mathrm{C}$ until analysis.

Sample analysis. Serum iPTH, BALP, $25(\mathrm{OH}) \mathrm{D}$, and $1,25(\mathrm{OH})_{2} \mathrm{D}$ were analyzed by Esoterix Clinical Trials Services. $\mathrm{PPTH}$ was measured by a solid phase 2-site chemiluminescence enzyme-labeled immunometric assay (Immulite 2000 System; Siemens). BALP was measured by chemiluminescence immunoassay (Access Immunoassay Systems; Beckman Coulter), and $25(\mathrm{OH}) \mathrm{D}$ and $1,25(\mathrm{OH})_{2} \mathrm{D}$ were measured by chemiluminescence immunoassay (LIAISON) and radioimmunoassay ( ${ }^{125}$ I-RIA), respectively (both from DiaSorin). Urinary Pi was measured colorimetrically (QuantiChrom Assay Kit, DIPI-500; BioAssay Systems), and intact FGF23 was measured using a validated two-site ELISA (Kainos Laboratories) at Kyowa Hakko Kirin California, Inc. Serum KRN23 concentrations were measured at Kyowa Hakko Kirin California, Inc. using a validated sandwich ELISA assay (data on file), which uses an anti-KRN23 mouse monoclonal antibody as the capture antibody and a biotinylated anti-KRN23 monoclonal antibody as the detection antibody (both were supplied by Kyowa Hakko Kirin Co., Ltd.). Using a streptavidin-alkaline phosphatase conjugate to catalyze the chemiluminescent substrate, the resultant chemiluminescent light intensity was measured, and the concentrations of KRN23 were calculated. The calibration range was $50-3,000 \mathrm{ng} / \mathrm{ml}$. The lower limit of quantification was $50 \mathrm{ng} / \mathrm{ml}$. The assay accuracy (relative error) and precision (coefficient of variation for the mean) were within acceptance criteria (less than $\pm 20 \%$ ) for all samples except two outliers at low KRN23 concentrations. Ten individual lots of pooled human serum were spiked with $50 \mathrm{ng} / \mathrm{ml}$ of KRN23. The relative error of detection ranged from $-11.4 \%$ to $7.2 \%$, whereas all unspiked individual lots yielded concentrations below the low limit of quantification (50 ng/ml), confirming the selectivity of the assay.

Anti-KRN23 antibodies were assayed using a validated sandwich ELISA. A sequential screening algorithm performed at Kyowa Hakko Kirin California, Inc. used an initial screening assay, a subsequent immunodepletion assay, and a neutralizing assay. Testing only proceeded to the subsequent assay step if the earlier assay was positive.

All other biochemical outcomes were analyzed at local clinical laboratories. Statistics. For each KRN23 dose level and each route of administration, the differences in the change from baseline between active and placebo treatments were calculated as least squares means with relevant $95 \% \mathrm{CI}$ and $P$ values using an ANOVA model. A $P$ value of less than 0.05 was considered statistically significant. A power model was used to assess dose proportionality for KRN23 AUC $C_{\text {inf }}$ and PD AUC last measures as follows: $\log \left(\mathrm{AUC}_{\text {inf }}\right.$ or $\left.A \mathrm{AUC}_{\text {last }}\right)=$ $\mu+\beta \times \log ($ dose), where $\mu$ described the mean value and $\beta$ (defining slope) described the proportionality between the administered dose of KRN23 and the $\mathrm{AUC}_{\text {inf }}$ for $\mathrm{KRN} 23$ or the $\mathrm{AUC}_{\text {last }}$ for PD parameters. If $95 \% \mathrm{CI}$ for $\beta$ did not contain 0 and contained 1 , dose proportionality was demonstrated.

All patients who received KRN23 or placebo were included in the safety and efficacy analyses. Primary PD outcome measures included TmP/GFR, serum $\mathrm{Pi}$, and serum $1,25(\mathrm{OH})_{2} \mathrm{D}$, and secondary PD outcomes included other biochemical markers described in Table 1 . The absolute values and changes from baseline were analyzed by treatment group. The number and percentage of patients reporting AEs were enumerated for each dosing cohort and treatment group. Statistical analysis was performed by Kyowa Hakko Kirin Pharma, Inc. using SAS software, version 9.

PK parameters were estimated using a noncompartmental analysis method (17). PK parameters included terminal elimination $t_{1 / 2}, A U U C_{\text {inf }}, C_{\max }, T_{\max }$, total clearance $\left(\mathrm{CL}=\right.$ dose $\left./ \mathrm{AUC}_{\text {inf }}\right)$ for i.v. dosing, and absolute bioavailability for s.c. administration ( $\mathrm{AUC}_{\text {inf }}$ for s.c./ $\mathrm{AUC}_{\text {inf }}$ for i.v., at the same dosing level). $\mathrm{PD}$ parameters included the $\mathrm{AUC}_{\text {last }}$ for the changes from baseline in serum Pi, $1,25(\mathrm{OH})_{2} \mathrm{D}$, and TmP/GFR. PD changes from baseline were calculated by subtracting the day 1 pre-dose value from values at each after-dose time point. If a pre-dose value was not available, the value at screening was used (2 cases). All PK parameters and the $\mathrm{AUC}_{\text {last }}$ for PD parameters were derived using WinNonlin software (version 5 for PK and version 6 for PD; Pharsight).

Study approval. This clinical study was conducted according to Declaration of Helsinki principles under an FDA-approved Investigational New Drug Application and with IRB approval from the Copernicus Group (Research Triangle Park, North Carolina, USA); the Committee for the Protection of Human Subjects at the University of Texas Health Science Center (Houston, Texas, USA); the Research Compliance Administration at Indiana University (Indianapolis, Indiana, USA); and the Human Investigation Committee at the Yale University School of Medicine (New Haven, Connecticut, USA). Written informed consent was received from all patients prior to inclusion in the study.

\section{Acknowledgments}

This work was made possible in part by CTS Awards UL1TR000142 (Yale University) and UL1TR001108 (Indiana University) from the National Center for Research Resources (NCRR) and the National Center for Advancing Translational Science (NCATS) of the NIH. We thank David Goltzman (McGill University School of Medicine) and Suzanne Jan de Beur (The Johns Hopkins Bayview Medical Center) for independent data and safety review during the course of the study. We thank Val Barra and Yamamoto Katsuhiko for analyses of KRN23 and antidrug antibodies (Kyowa Hakko Kirin California, Inc.). We thank Michael Econs (Indiana University School of Medicine) for assistance with development of the protocol. We thank Shirley McKernan and Peter Todd for providing medical writing services on behalf of Kyowa Hakko Kirin Pharma, Inc. We are particularly grateful to the dedicated patients who participated in the study and to the clinical study coordinators and research nursing staff at the four study sites (Yale University School of Medicine, Indiana University, Duke University Medical Center, and the University of Texas Health Science Center).

Received for publication August 21, 2013, and accepted in revised form December 17, 2013.

Address correspondence to: Thomas O. Carpenter, Department of Pediatrics (Endocrinology), Yale University School of Medicine, 333 Cedar Street, PO Box 208064, New Haven, Connecticut 065208064, USA. Phone: 203.785.6526; Fax: 203.737.4290; E-mail: thomas.carpenter@yale.edu.
1. Imel EA, Econs MJ. Fibroblast growth factor 23: roles in health and disease. J Am Soc Nephrol. 2005; 16(9):2565-2575.

2. Liu S, Quarles LD. How fibroblast growth factor 23 works. J Am Soc Nephrol. 2007;18(6):1637-1647.

3. Gattineni J, et al. FGF23 decreases renal NaPi-2a and $\mathrm{NaPi}-2 \mathrm{c}$ expression and induces hypophosphatemia in vivo predominantly via FGF receptor 1. Am J Physiol Renal Physiol. 2009;297:F282-F291.
4. Larsson $\mathrm{T}$, et al. Transgenic mice expressing fibroblast growth factor 23 under the control of the $\alpha 1$ (I) collagen promoter exhibit growth retardation, osteomalacia, and disturbed phosphate homeostasis. Endocrinology. 2004;145(7):3087-3094.

5. Shimada T, et al. FGF-23 transgenic mice demonstrate hypophosphatemic rickets with reduced expression of sodium phosphate cotransporter type IIa. Biochem Biophys Res Commun. 2004;
314(2):409-414

6. Tenenhouse HS, Econs NJ. Mendelian hypophosphatemia. In: Valle D, et al., eds. The Online Metabolic and Molecular Bases of Inherited Disease. Part 21, Chapter 197. http://ommbid.mhmedical.com/ book.aspx?bookID=474\#45374201. OMMBID Web site. Accessed January 22, 2014.

7. Reid IR, Hardy DC, Murphy WA, Teitelbaum SL, Bergfeld MA, Whyte MP. X-linked hypophospha- 
temia: a clinical, biochemical, and histopathologic assessment of morbidity in adults. Medicine (Baltimore). 1989;68(6):336-352.

8. Costa T, et al. X-linked hypophosphatemia: effect of calcitriol on renal handling of phosphate, serum phosphate, and bone mineralization. J Clin Endocrinol Metab. 1981;52(3):463-472.

9. Carpenter T, Imel EA, Holm IA, Jan de Beur SM, Insogna KL. A clinician's guide to X-linked hypophosphatemia. J Bone Miner Res. 2011;26(7):1381-1388.

10. Yamazaki Y, et al. Anti-FGF23 neutralizing antibodies show the physiological role and structural features of FGF23. J Bone Miner Res. 2008;23(9):1509-1518.

11. Aono Y, et al. Therapeutic effects of anti-FGF23 antibodies in hypophosphatemic rickets/osteomalacia. J Bone Miner Res. 2009;24(11):1879-1888.

12. Mayo Medical Laboratories. 2013 Online Test Catalog. Test ID: CACRU - Calcium/Creatinine Ratio, Random Urine. Mayo Clinic Web site. http://www.mayomedicallaboratories.com/ test-catalog/Clinical+and+Interpretive/89604. Accessed January 22, 2014.

13. Aono Y, et al. Anti-FGF-23 neutralizing antibodies ameliorate muscle weakness and decreased spontaneous movement of Hyp mice. J Bone Miner Res. 2011;26(4):803-810.

14. Moltz KC, Friedman AH, Nehgme RA, Kleinman CS, Carpenter TO. Ectopic cardiac calcification associated with hyperparathyroidism in a boy with hypophosphatemic rickets. Curr Opin Pediatr. 2001;13(4):373-375.

15. National Cancer Institute (NCI). Common Terminology Criteria for Adverse Events V3.0 (CTCAE). FEMH Web site. http://depart.femh.org.tw/ hema/html/CTCAE/CTCAE\%20V3.pdf. Accessed January 22, 2014

16. Walton RJ, Bijvoet OLM. Nomogram for derivation of renal threshold phosphate concentration. Lan- cet. 1975;2(7929):309-310.

17. Gibaldi M, Perrier D. Non-compartmental analysis based on statistical moment theory. In: Pharmacokinetics (Drugs and the Pharmaceutical Sciences). 2nd ed. New York, New York, USA: Marcel Decker Inc.; 1982:409-417.

18. Kratz A. Appendix: Laboratory values of clinical importance. In: Longo DL, Fauci AS, Kasper DL, eds. Harrison's Principles of Internal Medicine. 18 th ed. New York, New York, USA: McGraw Hill; 2012:3590-3602.

19. Investigator Laboratory Instruction Manual. Esoterix Clinical Trials Services. http://www. iristrial.org/teleforms/documents/LabCorp $\% 20$ Manual\%20v.8.pdf. Accessed January 22, 2014.

20. Yamazaki Y, et al. Increased circulatory level of biologically active full-length FGF-23 in patients with hypophosphatemic rickets/osteomalacia. J Clin Endocrinol Metab. 2002;87(11):4957-4960. 